\title{
PENERAPAN MODEL PEMBELAJARAN KOOPERATIF TIPE TPS (THINK-PAIR- SHARE) DAPAT MENINGKATKAN HASIL BELAJAR MENYIMAK DIALOG PENDEK BAHASA INGGRIS
}

\author{
Hadi Wibowo ${ }^{1, *}$ \\ ${ }^{1}$ Jurusan Pendidikan Bahasa Inggris, Universitas Pendidikan Ganesha
}

\begin{abstract}
Abstrak
Penelitian ini bertujuan untuk meningkatkan hasil belajar siswa melalui penerapan model pembelajaran kooperatif tipe Think Pair Share (TPS). Subjek dari penelitian ini adalah siswa kelas XI A 5 SMK Negeri 2 Singaraja tahun pelajaran 2017/2018. Kelas ini terdiri dari 41 orang siswa dengan komposisi siswa yaitu 18 orang perempuan dan 23 orang laki-laki. Dipilihnya siswa ini sebagai subjek penelitian dikarenakan siswa ini memiliki kemampuan yang rendah terhadap pemahaman menyimak sebelumnya. Obyek dari penelitian ini adalah hasil belajar menyimak dialog pendek bahasa Inggris. Lokasi Penelitian ini yaitu di kelas XI A 5 SMK Negeri 2 Singaraja. Penelitian ini didasarkan pada observasi awal yang mengindikasikan siswa memiliki masalah dalam menyimak. Sesuai dengan tujuan penelitian ini yaitu meningkatkan hasil belajar dalam menyimak maka penelitian ini dilakukan dalam bentuk penelitian tindakan kelas. Penelitian tindakan kelas (action research) ini dilukiskan dalam proses siklus atau spiral yang terdiri atas beberapa langkah yaitu perencanaan, tindakan, observasi, dan refleksi. Penelitian tindakan kelas ini dilaksanakan dalam 2 siklus. Masing- masing siklus terdiri dari tiga session yang mana dua session untuk tindakan dan satu session lagi untuk test. Hasil penelitian ini menunjukkan bahwa hasil belajar menyimak siswa meningkat dengan menerapkan model pembelajaran kooperatif tipe Think Pair Share (TPS). Ini bisa dilihat dari rata-rata skor siswa dalam test. Rata-rata skor siswa pada pre test adalah 54,50. Kemudian meningkat menjadi 72,75 pada siklus I. Hasil ini tidak memuaskan karena belum memenuhi kriteria ketuntasan yang sudah ditargetkan peneliti. Hasil dari skor siswa meningkat setelah peneliti memodifikasi kegiatan belajar mengajar pada siklus II. Sebagai hasilnya rata - rata skor siswa meningkat menjadi 85,75 dan 95\% siswa sudah mencapai ketuntasan belajar yang berarti sudah melebihi dari yang ditargetkan yaitu 75\%. Dari hasil penelitian tersebut bisa disimpulkan bahwa penerapan model pembelajaran kooperatif tipe TPS (Think Pair Share) bisa meningkatkan kemampuan menyimak siswa
\end{abstract}

\section{PENDAHULUAN}

Memasuki era globalisasi yang ditandai dengan persaingan ketat dalam berbagai sektor, maka setiap negara dituntut untuk memiliki daya saing yang kuat sehingga mampu menyejajarkan diri dengan negara-negara lain. Daya saing dapat dimiliki apabila negara tersebut didukung oleh sumber daya manusia yang handal. Proses pendidikan baik formal maupun informal merupakan sarana untuk membentuk sumber manusia yang handal yang menguasai ilmu pengetahuan dan teknologi. Sejalan dengan hal tersebut, penguasaan bahasa asing sebagai bahasa internasional perlu ditingkatkan, salah satunya adalah penguasaan bahasa Inggris.

Dalam pembelajaran berbahasa khususnya bahasa Inggris, terdapat empat aspek sentral yang harus dimiliki apabila ingin terampil dalam berbahasa, aspek- aspek tersebut antara lain, menyimak (Listening skills), berbicara (Speaking Skills), membaca (Reading Skills), menulis (Writing Skills).

Dalam proses interaksi dan komunikasi, diperlukan keterampilan berbahasa aktif, kreatif, produktif, dan reseptif apresiatif yang salah satu unsurnya adalah keterampilan menyimak yang bertujuan untuk menangkap dan memahami pesan, ide atau gagasan yang terdapat pada materi atau bahasa simakan. Dengan demikian, menyimak sangat penting dalam proses belajar mengajar. Proses pembelajaran merupakan interaksi antara guru dengan siswa dan antara siswa dengan siswa. Dalam rangka mencapai tujuan pembelajaran diperlukan suatu metode pembelajaran yang tepat sesuai dengan kondisi dan situasi dalam proses belajar mengajar. Interaksi yang baik antara siswa dan guru akan dapat mencapai tujuan belajar apabila suasana yang terjadi menyenangkan dan bermakna bagi siswa dan guru.

* Corresponding author.

E-mail Addresses: hadywibowo438@gmail.com (Hadi Wibowo) 
Kegiatan mendengarkan (menyimak) sebagai salah satu kegiatan berbahasa merupakan keterampilan yang cukup mendasar dalam aktivitas komunikasi. Hal ini dibuktikan oleh Wilga M. Rivers( Yusmartini:2008), yang menyatakan bahwa kebanyakan orang dewasa menggunakan $45 \%$ waktunya untuk menyimak, 30\% untuk berbicara, $15 \%$ untuk membaca dan 10\% untuk menulis. Berdasarkan kenyataan tersebut tampak jelas bahwa keterampilan menyimak harus dibina dan ditingkatkan karena keterampilan menyimak sangat dibutuhkan oleh manusia, baik untuk kebutuhan sehari-hari maupun untuk kepentingan di lingkungan pendidikan.

Merdhana (1984:2) menyatakan bahwa di sekolah-sekolah sebagian besar informasi itu bersifat lisan. Oleh karena itu, perlu kemampuan menyimak untuk memahami informasi lisan itu. Pengalaman peneliti sebagai siswa, juga merupakan bukti menyimak sangat dominan dalam kehidupan belajar, tidak hanya belajar berbahasa tapi juga belajar disiplin ilmu yang lain. Karena itu kemampuan menyimak akan turut menentukan prestasi dalam belajar di sekolah. Pada umumnya, siswa yang mempunyai prestasi yang tinggi dalam bidang akademis akan mempunyai kemampuan menyimak yang tinggi. Demikian pula sebaliknya, siswa yang mempunyai kemampuan menyimak sangat lemah mempunyai prestasi akademis yang lemah pula.

Di lingkungan pendidikan, khususnya di tingkat sekolah kejuruan, keterampilan menyimak sangatlah penting mengingat setiap Ujian Nasional siswa dihadapkan pada soal-soal mendengarkan teks. Kemampuan ini akan turut menentukan prestasi belajar siswa di sekolah. Namun demikian oleh sebagian besar siswa menganggap bahwa kegiatan menyimak adalah kegiatan yang sulit dibandingkan dengan kegiatan pembelajaran yang lain. Lebih lebih pelajaran menyimak telah dianggap kegiatan yang membosankan, baik oleh siswa maupun oleh guru yang mengajarnya. Penyempurnaan kemampuan menyimak diperlukan untuk memberikan hasil yang signifikan dalam mempelajari bahasa. Meski begitu masih ditemukan berbagai hambatan dalm proses pembelajarannya, baik pada guru, siswa, maupun materi simakan yang diberikan. Ini dapat dibuktikan dari observasi awal yang dilakukan oleh peneliti sendiri. Data yang diperoleh menunjukkan bahwa hasil atau nilai yang diperoleh siswa dalam hal menyimak masih sangat rendah, rata- rata 54,50. Padahal nilai ketuntasan belajar adalah 78,00. Ini berarti keterampilan menyimak memang mengalami permasalahan dan harus dicarikan jalan keluarnya. Salah satu cara yang biasa ditempuh adalah dengan memanfaatkan metode pembelajaran yang inovatif, kreatif , aktif, efektif, dan menyenangkan.

Berangkat dari fenomena tersebut, perlu diupayakan model pembelajaran yang mampu memberdayakan keterampilan menyimak siswa dalam pembelajaran untuk meningkatkan aktivitas dan hasil belajar. Model pembelajaran yang peneliti maksud adalah pembelajaran kooperatif TPS( Think-PairShare). Ini merupakan jenis pembelajaran kooperatif yang dirancang untuk mempengaruhi pola interaksi siswa. Dengan prosedur yang digunakan dalam Think-Pair-Share dapat memberi siswa lebih banyak waktu berfikir, untuk merespon dan saling membantu.

\section{METODE PENELITIAN}

Metode atau cara pendekatan yang dilakukan dalam penelitian ini adalah penelitian tindakan kelas. Artinya, penelitian yang dilakukan berbasis kelas dan dilakukan di dalam kelas, adanya pengajaran atau pembelajaran dalam rangka perbaikan hasil pembelajaran, sehingga perlu dilakukan secara bertahap atau multisiklus. Penelitian tindakan kelas menawarkan suatu cara dan prosedur baru untuk memeperbaiki dan meningkatkan kualitas proses belajar mengajar di kelas.Wendra(2007:45) menyatakan bahwa penelitian tindakan kelas merupakan penelitian yang dilakukan dengan melakukan tindakan tertentu dalam rangka memecahkan masalah yang dihadapi oleh guru dalam pembelajran. Artinya apabila seorang guru dihadapkan pada suatu permasalahan dalam pembelajaran, guru harus segera mengambil suatu tindakan untuk memecahkan masalah tersebut. Semua tindakan yang dilakukan tersebut dikemas dalam suatu bentuk penelitian yang disebut dengan Penelitian Tindakan Kelas (PTK). Dalam pelaksanaanya PTK dibagi menjadi beberapa tahap atau dikenal dengan istilah multisiklus. Sukardi (2004: 212) menyatakan bahwa salah satu karakteristik penelitian kelas adalah adanya langkah-langkah penelitian yang direncanakan dalam bentuk siklus, tingkatan atau daur yang memungkinkan terjadi kerja kelompok maupun kerja mandiri secara intensif.

Jadi dapat disimpulkan bahwa penelitian tindakan kelas dilaksanakan dalam rangka memecahkan suatu masalah demi perbaikan dan peningkatan kualitas pembelajaran dalam kelas. Untuk itu, tindakan dilakukan secara bertahap. Adapun tempat dan waktu dilaksanakannya penelitian ini adalah di kelas XI A 5 SMK Negeri 2 Singaraja pada semester ganjil tahun pelajaran 2017-2018. Metode Pengumpulan Data. Metode pengumpulan data digunakan dalam penelitian ini menggunakan tes hasil belajar. Dibawah ini adalah penjelasan dari metode tersebut: Metode Observasi adalah instrument lain yang sering dijumpai dalam penelitian pendidikan. Langkah ini bertujuan untuk mengamati, mengetahui, mencatat setiap gejala 
yang terjadi dalam ruang lingkup penelitian. Metode tes digunakan untuk mengumpulkan data tentang kemampuan siswa dalam menyimak. Tes yang dijadikan instrument adalah tes yang dibuat oleh guru untuk memperoleh gambaran mengenai hasil belajar siswa, khususnya dalam pembelajaran menyimak. Tes dibagi menjadi dua test yaitu pre test dan post test. Pre test akan diberikan sebelum tindakan dilakukan. Tes ini digunakan untuk mengetahui kemampuan siswa dalam hal menyimak dialog pendek sebelum tindakan dilakukan. Post test akan diberikan setelah tindakan selesai dilakukan pada akhir masing - masing siklus. Post test digunakan untuk mengetahui hasil dari implementasi model pembelajaran kooperatif tipe TPS (Think-Pair-Share) yang telah dilakukan di kelas. Jenis test adalah dalam bentuk pilihan ganda.

\section{HASIL DAN PEMBAHASAN}

Berdasarkan hasil penelitian yang telah diuraikan tersebut, terdapat beberapa temuan bermakna, antara lain sebagai berikut, 1) siswa kelas XI A 5 SMK N 2 Singaraja mampu menyimak dengan lebih baik berkat dibantu dengan menggunakan model pembelajaran kooperatif tipe TPS (Think-Pair-Share). Melalui pembelajaran kooperatif kemampuan sosial siswa akan meningkat dalam memecahkan masalah, memimpin dan sikap menghargai bersama. Dalam hal hubungan sosial, siswa merasa diterima dan diperhatikan sehingga menumbuhkan rasa saling menerima satu sama lainnya. Suasana kelas, dalam setting model pembelajaran kooperatif tipe TPS (Think-Pair-Share) dapat dilakukan dengan menyenangkan, sehingga dapat mendukung peningkatan akademik siswa. Dalam hal pengetahuan diri dan realisasi diri, siswa akan mengetahui kekurangan maupun kelebihan yang mereka miliki melalui balikan yang diberikan oleh yang lain. 2) Siswa menjadi senang dalam mengikuti pembelajaran menyimak karena adanya kelompok-kelompok belajar. 3) Penggunaan model pembelajaran kooperatif tipe TPS (Think-Pair-Share) dalam pembelajaran menyimak terbukti dapat meningkatkan hasil belajar siswa.

Berdasarkan tabel diatas, dapat dilihat nilai siswa dari sebelum diadakan tindakan sampai siklus I ada penurunan nilai siswa sebanyak 2 orang, 2 orang nilainya tetap dan 16 orang mengalami peningkatan akan tetapi masih belum bisa dikatakan tuntas karena masih ada siswa yang nilainya dibawah nilai KKM. Sebanyak 10 orang dinyatakan tuntas karena sudah memenuhi kriteria ketuntasan minimum ( KKM ), dan 10 orang dinyatakan belum bisa mmenuhi KKM. Artinya dari sebelum diadakan tindakan sampai pada siklus I peningkatan nilai belum mencapai ketuntasan yang maksimal, hal itu disebabkan sebagian siswa masih ribut, dan masih belum begitu memahami listening yang diperdengarkan. Pada siklus I sampai siklus II, perbandingan nilai siswa yaitu tidak ada siswa yang mengalami penurunan nilai pada siklus II. Semua siswa mengalami peningkatan hasil belajar tetapi ada 1 orang siswa belum bisa mencapai nilai KKM. Proses pembelajaran pada tindakan II terjadi peningkatan nilai sebesar 95\%. Oleh karena itu tindakan pada siklus II dapat diselesaikan karena telah terjadi peningkatan nilai. Hal ini terbukti dari hasil evaluasi menyimak siswa yang mengalami peningkatan yang cukup signifikan, yaitu dari nilai ratarata kelas sebelum pelaksanaan tindakan adalah 54.50. Sementara itu, setelah pelaksanaan tindakan nilai rata-rata klasikal siswa menjadi 72,75 pada siklus I dan 85,75 pada siklus II.

Jadi, penggunaan model pembelajaran kooperatif tipe TPS (Think-Pair-Share) dapat meningkatkan hasil belajar siswa kelas XI A 5 SMK N 2 Singaraja dalam hal menyimak.

\section{KESIMPULAN DAN SARAN}

Rendahnya aktivitas belajar dan prestasi belajar disebabkan oleh faktor-faktor seperti metode yang digunakan guru, sehingga penggunaan atau penggantian metode konvensional menjadi metode-metode yang sifatnya konstruktivis sangat diperlukan, akibatnya peneliti mencoba Model Pembelajaran Kooperatif Tipe TPS (Think-Pair-Share) dalam upaya untuk dapat memecahkan permasalahan yang ada. Penggunaan model pembelajaran Model Pembelajaran Kooperatif Tipe TPS (Think-Pair-Share) diupayakan untuk dapat menyelesaikan tujuan penelitian ini yaitu untuk mengetahui peningkatan hasil belajar.

Dalam penelitian ini, ada beberapa temuan bermakna bagi SMK N 2 Singaraja yang menjadi tempat dilakukannya penelitian ini. Temuan tersebut diantaranya adalah 1) siswa mau dan mampu menyimak dialog pendek dengan sungguh-sungguh karena diberikan motivasi oleh guru, 2) Model pembelajaran Koopertif Tipe TPS (Think-Pair-Share) sangat membantu siswa dalam menyimak. 3) Siswa merasa senang mengikuti kegiatan pembelajaran meyimak dengan menggunakan Model Pembelajaran Koopertif Tipe TPS (Think-Pair-Share). 4)Pemanfaatan Model Pembelajaran Koopertif Tipe TPS (Think-Pair-Share) dapat meningkatkan hasil belajar menyimak siswa. Seberapa besar peningkatan yang dicapai sudah dipaparkan dengan jelas pada akhir analisis. Dari hasil penelitian di Bab IV. Berdasar pada semua data yang telah disampaikan tersebut. Tujuan penelitian yang disampaikan di atas dapat dicapai dengan bukti sebagai 
berikut: a) Dari data awal ada 19 siswa mendapat nilai dibawah 78 dan pada siklus I menurun menjadi 10 siswa dan siklus II hanya 1 siswa mendapat nilai dibawah 78, b) Dari rata-rata awal 54,50 naik menjadi 72,75 pada siklus I dan pada siklus II naik menjadi 85,75 , c) Dari data awal siswa yang tuntas hanya 1 orang sedangkan pada siklus I menjadi lebih banyak yaitu 10 siswa dan pada siklus II menjadi cukup banyak yaitu 19 siswa.

Berdasarkan uraian diatas dapat ditarik beberapa simpulan yaitu sebagai berikut: 1) Pemanfaatan Model Pembelajaran Kooperatif Tipe TPS (Think-Pair-Share) dalam pembelajaran menyimak dapat meningkatkan hasil belajar siswa kelas XI A 5 SMK N 2 Singaraja terhadap dialog pendek bahasa inggris, 2) Langkah - langkah dan cara guru dalam membelajarkan materi menyimak dialog pendek pada siswa sangat inovatif. Dengan membentuk kelompok kerja, membuat pembelajaran menjadi lebih menarik, 3) Dengan menggunakan model pembelajaran inovatif, mampu menumbuhkan motivasi belajar siswa, sehingga ada kecenderungan adanya peningkatan hasil belajar siswa. Dengan demikian, dapat dikatakan bahwa ada korelasi antara pemilihan media pembelajaran yang inovatif terhadap hasil belajar siswa.

Berdasarkan simpulan di atas, dapat peneliti sarankan beberapa hal, sebagai berikut: 1) Para guru Bahasa Inggris yang mengajar di kelas XI SMK dapat memanfaatkan Model Pembelajaran Kooperatif Tipe TPS (Think-Pair-Share) dalam pembelajaran menyimak agar hasil pembelajaran menyimak siswa dapat ditingkatkan dan dalam memilih media pembelajaran, guru harus menyesuaikan materi yang akan disimak, 2) Para siswa disarankan lebih aktif dalam mengikuti pembelajaran dan selalu menumbuhkan rasa senang untuk menyimak karena keterampilan menyimak merupakan kunci untuk mampu menguasai ketiga keterampilan lainnya, yakni berbicara, membaca dan menulis, 3) Para peneliti diharapkan untuk melaksanakan penelitian sejenis dengan latar belakang dan subjek yang berbeda mengingat nilai keterampilan menyimak siswa dalam penelitian ini meningkat dan model yang diterapkan ampuh untuk meningkatkan kemampuan siswa dalam menyimak.

\section{DAFTAR PUSTAKA}

Arends. 1997. http://jurnalbidandiah.blogspot.com/2012/04/model-pembelajaran-tipe-think-pair.html

Agustini. 2010. Penerapan Model Pembelajaran tipe Jigsaw dalam Bahasa Indonesia untuk meningkatkan keterampilan menyimak siswa kelas VIID SMP Negeri 1 Kerambitan. Universitas Pendidikan Ganesha: tidak diterbitkan

Depdiknas. 2011. Rancangan Silkus Penelitian Tindakan Kelas (PTK). Jakarta: Depdikbud.

Dimyati dan Mudjiono. 2006. http://eprints.uny.ac.id/9829/2/bab2.pdf.

Gunamantha dan Sukarta. 2006. Metode Pembelajaran Kooperatif. Jakarta: Duta Wacana University Press.

Hanapi. 1995. Peningkatan Keterampilan Berbahasa Indonesia. Jakarta. Depdikbud.

Merdhana. I Nyoman. 1984. Dasar - dasar Menyimak Efektif. Singaraja: Fakultas Keguruan dan Ilmu Pendidikan.

Sudjana, Nana. 2009. http://eprints.uny.ac.id/9829/2/bab2.pdf.

Sugihartono, dkk. 2007. http://eprints.uny.ac.id/9829/2/bab2.pdf.

Sukardi. 2004. Metodologi Penelitian Pendidikan. Yogyakarta: PT. Bumi Angkasa.

Tarigan, Hendry Guntur. 1994. Menyimak sebagai suatu Keterampilan Berbahasa. Bandung: Angkasa.

Wahono dan Rusmiyanto. 2004. Kreatif bersastra dan Berbahasa Indonesia. Bandung: Ganesha Exact.

Wendra, I Wayan. 2007. Buku Ajar Penulisan Karya Ilmiah. Singaraja. Universitas Pendidikan Ganesha Yusmartini, Putu Prima. 2008. Upaya Meningkatkan Kemampuan Menyimak Dongeng dengan Menggunakan Tape Recorder disertai Gambar Berseri Siswa SD Lab Undiksha Singaraja. Universitas Pendidikan Ganesha: tidak diterbitkan. 